\title{
MANAJEMEN PROGRAM KEGIATAN PAUD BERBASIS OTAK KANAN
}

\author{
Siswadi \\ IAIN Purwokerto \\ E-mail: siswadi@gmail.com \\ Novan Ardy Wiyani \\ IAIN Purwokerto \\ E-mail: fenomenajiwa@gmail.com
}

Article received: 05 Maret 2018, Review process: 10 Maret 2018

Article published: 30 Maret 2018

\begin{abstract}
This research is field research by using qualitative approach aimed to get the derskripsi about management of right brain based PAUD program in TK Khalifah Purwokerto. Data were collected using interview technique, observation, and documentation. The data has been collected and then analyzed using data analysis technique inductively. Based on the results of research can be known that the optimization of right brain development in early childhood in kindergarten Caliph Purwokerto done through the internalization of the value of tauhid and entrepreneur in early childhood. Thematic learning and habituation became the program of early childhood activities that serve as a media for the internalization of tauhid and entrepreneur values. To ensure the internalization of the monotheistic and entrepreneurial values in an effective and efficient way, four managerial activities, namely the right-brain PAUD program, the right-brain PAUD program, the right-brain PAUD program, and the PAUD program based right brain.
\end{abstract}

Keywords: management, early childhood, tauhid, entrepreneur

\begin{abstract}
Abstrak
Penelitian ini merupakan penelitian lapangan (field research) dengan menggunakan pendekatan kualitatif yang ditujukan untuk mendapatkan derskripsi tentang manajemen program kegiatan PAUD berbasis otak kanan di TK Khalifah Purwokerto. Data dikumpulkan menggunakan teknik wawancara, observasi, dan dokumentasi. Data yang telah terkumpul kemudian dianalisis menggunakan teknik analisis data secara induktif. Berdasarkan hasil penelitian dapat diketahui bahwa optimalisasi pengembangan otak kanan pada anak usia dini di TK Khalifah Purwokerto dilakukan melalui internalisasi nilai tauhid dan entrepreneur pada anak usia dini. Pembelajaran tematik dan pembiasaan menjadi program kegiatan PAUD yang dijadikan sebagai media internalisasi nilai tauhid dan entrepreneur.Untuk memastikan proses internalisasi nilai tauhid dan entrepreneur berlangsung dengan efektif dan efisien, maka dilakukanlah empat kegiatan manajerial, yaitu perencanaan program kegiatan PAUD berbasis otak kanan, pengorganisasian
\end{abstract}


program kegiatan PAUD berbasis otak kanan, pelaksanaan program kegiatan PAUD berbasis otak kanan, dan penilaian program kegiatan PAUD berbasis otak kanan.

Kata kunci: manajemen, PAUD, tauhid, entrepreneur.

\section{PENDAHULUAN}

Pendidikan merupakan salah satu faktor penentu keberhasilan pembangunan nasional. Dengan pendidikan, Sumber Daya Manusia (SDM) bangsa Indonesia menjadi berkualitas dan siap bersaing di kancah global. Berbagai upaya dilakukan oleh pemerintah untuk menyiapkan SDM bangsa yang berkualitas. Bongkar-pasang kurikulum pun dilakukan untuk mewujudkannya.

Kurikulum berbasis kompetensi kemudian diterapkan untuk melahirkan SDM bangsa yang berkualitas. Pada satu sisi, penerapan kurikulum berbasis kompetensi telah berhasil meningkatkan kualitas IPTEKS, tetapi di pihak lain kompetensi di bidang karakter terabaikan. Padahal, karakter merupakan suatu pondasi bangsa yang sangat penting dan perlu ditanamkan sejak dini kepada anak-anak (Ningsih, 2015: 1). Pendidikan hingga saat ini hanya mampu melahirkan peserta didik yang cerdas intelektualnya (IQ) dan belum mampu melahirkan peserta didik yang memiliki kecerdasan emosional dan spiritual (ESQ).

IQ identik dengan fungsi otak kiri manusia. Sedangkan ESQ identik dengan fungsi otak kanan manusia. Praktik pendidikan saat ini lebih fokus pada otak kiri dan mengabaikan otak kanan. Indikatornya adalah sistem pendidikan saat ini cenderung mengarahkan peserta didik untuk hanya menerima satu jawaban dari permasalahan. Jawaban itulah yang kemudian diajarkan oleh guru untuk kemudian diulangi oleh peserta didik dengan baik pada saat ujian. Tak ada ruang untuk berpikir lateral, berpikir alternatif, mencari jawaban yang nyleneh, terbuka, dan memandang ke arah lain. Akibatnya peserta didik menjadi individu yang berpikir linear, kurang demokratis, dan kurang humanis.

Pada seluruh jenjang pendidikan di Indonesia, praktik penyelenggaraan pendidikan dari jenjang Pendidikan Anak Usia Dini (PAUD) hingga Pendidikan Tinggi lebih menekankan pengembangan otak kiri daripada otak kanan. Akibatnya pendidikan tidak akan menghasilkan anak-anak yang berkepribadian utuh (Suyadi, 2015: 107).

Sebenarnya tidak ada keistimewaan yang mendasar dari otak kanan ketika otak kanan dibandingkan dengan otak kiri. Keduanya saling memiliki pengaruh dan berjalan berkelindan. Jika tidak ada otak kanan, otak kiri tidak akan bekerja maksimal, begitu juga sebaliknya. Namun demikian, seseorang yang mencerdaskan otak kanannya terlebih dahulu, maka otak kiri akan 
mengikutinya. Bila otak kanan anak dikembangkan dengan optimal, maka anak bukan hanya dapat menjadi pribadi yang kreatif, tetapi juga dapat menjadi pribadi yang empatik, optimisme, kepercayaan diri, kesabaran, ketawakkalan, dan tanggung jawab (Muhammad, 2009: 33). Ini berarti pengembangan otak kanan juga dapat dijadikan sebagai salah satu ikhtiar untuk membentuk karakter anak usia dini sebagai generasi emas bangsa Indonesia.

Ciri seorang anak yang memiliki kecerdasan pada otak kanannya adalah ia menjadi pribadi yang baik pada sesama dan rajin menjalankan ibadahnya. Biasanya ini terlihat ketika ia berinteraksi dengan sesama dan lingkungannya, sikapnya ramah dan baik pada siapa saja, tidak pernah membuka aib (kejelekan, kekurangan, dan kekhilafan) orang lain, serta mampu menangkap esensi dari agama yang dianutnya. Itulah sebab seseorang yang memiliki kecerdasan pada otak kanannya dikatakan ia cerdas secara emosional dan spiritual/ESQ (Kurniasih, 2010: 27).

Kecerdasan intelektual (IQ) yang identik dengan otak kiri menentukan kesuksesan seseorang sebesar 20\%. Sedangkan kecerdasan emosional (EQ) bersamaan dengan kecerdasan spiritual (SQ) yang identik dengan otak kanan berkontribusi terhadap kesuksesan seseorang sebesar 80\% (Kurniasih, 2010: 58). Jadi akan menjadi suatu kekeliruan jika kegiatan pendidikan di Indonesia lebih memfokuskan pada pengembangan otak kiri dan mengabaikan pengembangan otak kanan anak. kegiatan pendidikan mulai dari TK/RA hingga Pendidikan Tinggi harus mampu menyeimbangkan antara pengembangan otak kiri dengan otak kanan, serta mendahulukan pengembangan otak kanan.

Optimalnya perkembangan otak kanan akan diikuti oleh optimalnya perkembangan otak kiri. Pengembangan otak kanan sangat tepat jika dilaksanakan sejak usia dini. Anak yang cerdas otak kanannya akan menjadi anak yang cerdas otak kirinya dan dapat menjadi anak yang berkarakter (Suyadi dan Maulidya Ulfah, 2013: 175). Namun sayangnya, kegiatan Pendidikan Anak Usia Dini (PAUD) masih memfokuskan pada pengembangan otak kiri.

Indikasi kegiatan PAUD lebih fokus pada pengembangan otak kiri dan mengabaikan pengembangan otak kanan adalah masih mudahnya ditemukan praktik menghafal bagi anak usia dini, mulai dari menghafal Pancasila, menghafal pidato, menghafal puisi, hingga menghafal doadoa harian. Guru seakan lupa jika anak juga harus dibiasakan bagaimana mengamalkan nilainilai Pancasila, isi pidato, pesan-pesan dalam puisi, dan mempraktikkan doa-doa hariannya (Satibi, 2013: 2.13). 
Indikator lainnya adalah kegiatan PAUD lebih bersifat akademis. Anak lebih banyak diajarkan untuk dapat membaca, menulis, berhitung, serta menghafal data untuk mengembangkan otak kirinya. Sementara bentuk kegiatan PAUD yang dapat mengembangkan otak kanan, seperti menggambar, bermain musik, mengarang bebas, drama, dan berbagai pembiasaan jarang dilaksanakan (Rachmawati dan Euis Kurniati, 2010: 26).

Berdasarkan data hasil observasi penulis pada beberapa Taman Kanak-kanak (TK) Islam dan Raudhatul Athfal (RA) di Kabupaten Banyumas diperoleh beberapa temuan terkait dengan indikator lebih difokuskannya pengembangan otak kiri daripada otak kanan.

Pertama, ditemukan kegiatan PAUD yang lebih mengedepankan praktik hafalan suratsurat pendek, bacaan-bacaan ketika sholat dan doa-doa harian tanpa diikuti dengan kegiatan pembiasaan untuk mempraktikkannya. Akibatnya anak hanya "sekedar hafal" dan tidak mengerti bagaimana cara mengamalkan hafalan-hafalannya.Kedua, ditemukan kegiatan PAUD yang lebih mengedepankan pada kemampuan anak untuk bisa membaca, menulis, dan berhitung (CALISTUNG). Sedangkan berbagai kegiatan bermain yang dapat memacu kreativitas anak terabaikan. Alasannya adalah karena sebagian besar para orang tua menuntut kepada guru agar anaknya setamat dari TK/RA harus sudah bisa membaca. Ini karena ada Sekolah Dasar (SD) yang menjadikan kemampuan membaca, menulis, dan berhitung sebagai syarat masuk untuk dapat sekolah di SD tersebut.

Ketiga, ditemukan kegiatan PAUD yang didominasi dengan hafalan dan ceramahceramah dari para gurunya. Anak-anak dipaksa untuk datang, duduk, dan diam untuk mendengarkan ceramah dari guru mengerjakan perintah untuk menghafalkan suatu materi. Penyebabnya adalah karena keterbatasan alat permainan edukatif (APE) serta para guru belum mampu menyelenggarakan kegiatan PAUD yang sesuai dengan prinsip Developmentally Appropriate Practice (DAP). Kemampuan guru dalam menyelenggarakan kegiatan PAUD sesuai dengan prinsip DAP dipengaruhi oleh profesionalisme mereka sebagai guru.

Ada tiga penyebab mengapa pengembangan otak kiri lebih diutamakan daripada otak kanan. Pertama, guru belum memahami urgensi pengembangan otak kanan bagi anak usia dini. Kedua, guru belum mengetahui berbagai program kegiatan PAUD yang dapat digunakan untuk mengembangkan otak kanan anak usia dini. Ketiga, kepala TK/RA belum mampu mengelola program kegiatan PAUD yang berpihak pada pengembangan otak kanan anak usia dini.

Masalah pertama dan kedua memiliki keterkaitan dengan kompetensi pedagogik dan kompetensi profesional guru. Sedangkan masalah ketiga memiliki keterkaitan dengan 
kompetensi manajerial kepala TK/RA, bahkan bagaimana pengetahuan, pemahaman serta kemampuan guru dalam melaksanakan berbagai program kegiatan PAUD yang berpihak pada pengembangan otak kanan anak usia dini dipengaruhi oleh kompetensi manajerial kepala TK/RA.

Imbas dari lemahnya kompetensi manajerial kepala TK/RA adalah program kegiatan PAUD menjadi asal jalan. Selain itu, banyak kalangan yang menyebut manajemen di TK/RA sebagai "manajemen tukang cukur". Artinya, manajemen yang selama ini dijalankan oleh TK/RA dilakukan secara serabutan (Risaldy, 2014: 69). Maka pembenahan terhadap kompetensi manajerial kepala TK/RA sangat diperlukan jika ingin berbagai program kegiatan PAUD dapat dilaksanakan secara optimal dan dapat menjadikan anak usia dini sebagai pribadi yang utuh dan menyeluruh, yang bukan hanya cerdas otak kirinya, tetapi juga cerdas otak kanannya (Mulyasa, 2014: 2).

Jadi salah satu cara yang dapat digunakan untuk membenahi kompetensi manajerial kepala TK/RA sehingga mereka dapat menyelenggarakan program kegiatan PAUD yang berorientasi pada pengembangan otak kanan anak usia dini adalah dengan menemukan deskripsi manajemen program kegiatan PAUD berbasis otak kanan. Hasil temuan tersebut dapat dijadikan sebagai guideline bagi kepala TK/RA dalam menyelenggarakan berbagai program kegiatan PAUD berbasis otak kanan. Hal itulah yang menjadikan penulis tertarik untuk melakukan penelitian di TK Khalifah Purwokerto.

TK Khalifah didirikan oleh Ippo Santosa seorang pelopor dan pakar otak kanan di Indonesia. Kepakarannya di bidang otak kanan juga telah mendapatkan sertifikat dari MURI. Salah satu upaya yang dilakukan oleh Ippo Santosa dalam mengembangkan kecerdasan otak kanan anak usia dini adalah dengan mendirikan TK Khalifah dengan konsep kemitraan pada berbagai kota di Indonesia, salah satunya di Purwokerto. Berbagai program kegiatan PAUD dilaksanakan oleh TK Khalifah Purwokerto untuk mengembangkan kecerdasan otak kanan anak usia dini dengan menjadikan "tauhid dan entrepreneurship" sebagai core value-nya. Nilai tauhid dan entrepreneurship pun muncul dalam Rencana Kegiatan Mingguan (RKM) dan Rencana Kegiatan Harian (RKH) yang disusun dan diterapkan oleh guru TK Khalifah Purwokerto.

\section{LANDASAN TEORI}

\section{Manajemen Program Kegiatan PAUD}

Kata manajemen berasal dari bahasa Inggris, yaitu management dengan kata kerja to manage, diartikan secara umum sebagai mengurusi (Sulistyorini, 2009: 8). Kata to manage oleh 
Henri Fayol diartikan dengan meramal dan merencanakan atau to manage is forecasting and plan (Kimani, tt: 16). Manajemen sebagai sebuah proses mencangkup empat kegiatan utama, yaitu planning (perencanaan), organizing (pengorganisasian), actuating (pelaksanaan), dan controling (pengawasan atau penilaian). Keempat kegiatan tersebut diistilahkan dengan kegiatan manajerial. Pada kegiatan manajerial keempat kegiatan tersebut menjadi sebuah siklus karena adanya saling keterkaitan antara kegiatan yang pertama hingga kegiatan berikutnya (Sulistyorini, 2009: 27).

Pada pelaksanaannya, pekerjaan manajerial merupakan pekerjaan yang proses penyelesaiannya dilakukan dengan menggunakan tangan orang lain. Sedangkan pekerjaan teknis merupakan pekerjaan yang proses penyelesaiannya dilakukan dengan langsung menggunakan tangan sendiri. Dengan kata lain, pekerjaan manajerial merupakan pekerjaan pimpinan atau atasan, sedangkan pekerjaan teknis atau pekerjaan operasional merupakan pekerjaan staf. Jadi manajemen pada dasarnya merupakan suatu proses pengelolaan sumber daya secara efektif untuk mencapai sasaran atau tujuan tertentu.

Mursid mengungkapkan bahwa pendidikan anak usia dini adalah pemberian upaya untuk menstimulasi, membimbing, mengasuh, dan memberikan kegiatan pembelajaran yang akan menghasilkan kemampuan dan keterampilan anak. Sedangkan pendidikan bagi anak usia dini merupakan sebuah pendidikan yang dilakukan pada anak yang baru lahir hingga delapan tahun. Pendidikan pada tahap ini memfokuskan pada physical, intellegence, emotional, dan social education(Mursid, 2015: 15). Pengertian tersebut nampaknya mengacu pada The National Association for The Education for Young Children (NAECY) yang membuat klasifikasi anak usia dini pada rentang usia 0 hingga 8 tahun. Sementara di Indonesia, anak usia dini merupakan anak yang berusia 0 hingga 6 tahun (Mulyani, 2016: 7).Sedangkan program dapat diartikan sebagai suatu unit atau kesatuan kegiatan yang merupakan realisasi atau implementasi dari suatu kebijakan, berlangsung dalam proses yang berkesinambungan dan terjadi dalam suatu organisasi melibatkan sekelompok orang untuk meraih tujuan yang telah ditetapkan bersama.

Berdasarkan deskripsi di atas maka manajemen program kegiatan PAUD dapat diartikan sebagai suatu proses merencanakan, mengorganisasikan, melaksanakan dan mengevaluasi kegiatan-kegiatan bagi anak usia dini untuk mencapai tujuan PAUD dengan melibatkan stakeholders PAUD.

Perencanaan program kegiatan PAUD adalah suatu proses dan cara berpikir tentang upaya-upaya yang akan dilakukan dalam kegiatan PAUD untuk mencapai tujuan PAUD. Ada 
enam kegiatan yang dilakukan dalam perencanaan program kegiatan PAUD, yaitu perumusan tujuan PAUD, menetapkan program kegiatan PAUD, menyusun strategi program kegiatan, menyusun jadwal program kegiatan PAUD, dan menetapkan anggaran program kegiatan PAUD.

Pengorganisasian program kegiatan PAUD dapat diartikan sebagai upaya untuk menentukan dan mengatur hubungan serta aktivitas kerja dari sumber daya manusia yang terlibat dalam pelaksanaan kegiatan PAUD pada suatu lembaga PAUD untuk mencapai tujuan PAUD.Itulah sebab pengorganisasian program kegiatan PAUD berhubungan erat dengan struktur organisasi lembaga PAUD. Pengorganisasian merupakan suatu proses untuk merancang struktur formal, mengelompokkan dan mengatur serta membagi tugas-tugas atau pekerjaan di antara para anggota organisasi agar tujuan dan sasaran organisasi dapat dicapai dengan efisien. Ada tiga prosedur yang dilakukan dalam pengorganisasian program kegiatan PAUD.

Langkah-langkah yang dilakukan dalam pengorganisasian program kegiatan PAUD antara lain menetapkan penanggungjawab program kegiatan, menentukan siapa guru yang mengerjakan tugas pada program kegiatan PAUD, menetapkan tugas yang harus dikerjakan pada program kegiatan PAUD, dan memberdayakan sarana dan prasarana yang dimiliki oleh lembaga PAUD dalam melaksanakan kegiatan PAUD (Musbikin, 2013: 60).

Pelaksanaan program kegiatan PAUD adalah upaya merealisasikan program kegiatan PAUD yang telah direncanakan untuk mencapai tujuan PAUD melalui pendayagunaan sumber daya PAUD secara efektif dan efisien.Langkah-langkah yang dilakukan dalam pelaksanaan program kegiatan PAUD antara lain memberikan pengarahan kepada guru dan pihak lain yang terlibat pada program kegiatan PAUD yang telah ditentukan, memotivasi guru dan pihak lain untuk melaksanakan program kegiatan PAUD, memotivasi anak untuk berperan aktif dalam melaksanakan program kegiatan PAUD, dan menjalin komunikasi dengan wali murid untuk kepentingan pelaksanaan program kegiatan PAUD (Asmani, 2012: 54).

Penilaian program kegiatan PAUD dapat diartikan sebagai upaya yang dilakukan untuk menentukan keberhasilan program kegiatan PAUD yang telah dilaksanakan. Keberhasilan dalam pelaksanaan program kegiatan PAUD tersebut mencerminkan ketercapaian tujuan PAUD yang telah ditetapkan.Langkah-langkah yang dilakukan dalam penilaian program kegiatan PAUD antara lain menentukan aspek yang akan dinilai pada program kegiatan PAUD, menentukan indikator keberhasilan program kegiatan PAUD, menentukan teknik dan prosedur penilaian program kegiatan PAUD, melaksanakan penilaian sesuai dengan prosedur, mengambil keputusan mengenai keberhasilan program kegiatan PAUD, mendiagnosa masalah-masalah yang dihadapi 
dalam pelaksanaan program kegiatan PAUD, dan menentukan upaya perbaikan untuk mengatasi masalah-masalah yang dihadapi dalam pelaksanaan program kegiatan PAUD (Mulyasa, 2013: 193).

\section{Program Kegiatan PAUD}

Kurikulum merupakan elemen strategis dalam sebuah program pendidikan, termasuk salah satunya adalah dalam program kegiatan PAUD. Kurikulum merupakan "cetak biru" (blue print) atau acuan bagi semua pihak yang terkait dengan pelaksanaan program kegiatan PAUD (Umiarso dan Imam Gojali, 2010: 87).

Program kegiatan PAUD di Indonesia dilaksanakan menggunakan model kurikulum PAUD tematik-terpadu. Model kurikulum PAUD tematik-terpadu ini memfokuskan penyelenggaraan kegiatan belajar bagi anak berdasarkan tema-tema (pokok pikiran) tertentu yang di dalamnya terdapat berbagai materi yang dapat digunakan untuk mengoptimalkan kemampuan fisik-motorik, perkembangan agama dan moral, kognitif, bahasa, serta sosial dan emosi.

Berbagai tema tersebut ditentukan berdasarkan tumbuh-kembang anak serta keadaan lingkungan di sekitar anak. Contoh tema yang telah ditentukan seperti binatang, profesi, tumbuhan, manusia, dan lainnya.Model kurikulum PAUD tematik-terpadu di Indonesia secara umum dilaksanakan dengan menggunakan model pembelajaran sentra dan model pembelajaran kelompok.

Model pembelajaran sentra dapat juga diartikan sebagai proses pembelajaran yang berpusat pada anak yang dalam pelaksanaannya berpusat di sentra main dan saat anak dalam lingkaran dengan menggunakan empat pijakan untuk mendukung perkembangan anak, yaitu pijakan lingkungan main, pijakan sebelum main, pijakan selama main, dan pijakan setelah main (Masruroh, 2014: 45). Ada setidaknya enam sentra yang lazim digunakan oleh lembaga PAUD, yaitu sentra imtak, sentra bahan alam, sentra seni dan kreativitas, sentra bermain peran, sentra balok, dan sentra persiapan.

Model pembelajaran kelompok merupakan model pembelajaran di mana anak didik dibagi dalam beberapa kelompok dengan kegiatan yang berbeda-beda. Langkah-langkah kegiatan pembelajaran dengan model pembelajaran kelompok dibagi menjadi empat kegiatan, yaitu kegiatan pendahuluan/awal, kegiatan inti, istirahat/makan, dan penutup.

Pelaksanaan model pembelajaran sentra maupun model pembelajaran kelompok didukung oleh pelaksanaan kegiatan pembiasaan bagi anak usia dini. Ada dua jenis program 
kegiatan pembiasaan yang dapat dilaksanakan bagi anak usia dini, yaitu pembiasaan rutin dan pembiasaan spontan.

\section{Perkembangan Otak Anak}

Program kegiatan PAUD ditujukan untuk anak usia dini. Kemampuan anak dalam melaksanakan program kegiatan PAUD tersebut sangat dipengaruhi oleh perkembangan otaknya. Dalam perspektif neurosains, perkembangan fisik otak pada anak dapat dideskripsikan sebagai berikut:Pertama, ketika lahir sel-sel otak bayi berjumlah sekitar 100 miliar, tetapi belum saling berhubungan kecuali hanya sedikit, yaitu hanya sel-sel otak yang mengendalikan detak jantung, pernafasan, gerak refleks, pendengaran dan naluri hidup.Kedua, ketika anak berusia 3 tahun, sel otak telah membentuk sekitar 1000 triliun jaringan koneksi/sinapsis. Jumlah ini dua kali lebih banyak dari yang dimiliki oleh orang dewasa. Sebuah sel otak dapat berhubungan dengan 15000 sel lain. Sinaps-sinaps yang jarang digunakan akan mati, sedangkan yang sering digunakan akan semakin kuat dan permanen. Setiap rangsangan atau stimulasi yang diterima anak akan melahirkan sambungan baru aau memperkuat sambungan yang sudah ada (Suyadi dan Maulidya Ulfah, 2013: 3).

Perkembangan otak anak usia dini berjalan cepat, bahkan lebih cepat dari usia sesudahnya. Hal ini berkaitan dengan optimalisasi fungsi sel-sel syaraf (neuron). Otak manusia terdiri dari dua belahan (hemisfer), yaitu belahan kiri dan kanan yang berisi miliaran neuron. Masing-masing belahan memiliki fungsi yang berbeda. Belahan kiri (left hemisfer) bercirikan logis, rasional dan analitik. Sedangkan belahan kanan (right hemisfer) bercirikan kreatif, divergen, dan holistik.

Kedua belahan tersebut diupayakan berkembang seimbang untuk membentuk manusia seutuhnya. Agar kedua belahan tersebut berkembang optimal, maka dibutuhkan peranan orang dewasa untuk membantu, yaitu dengan memberikan rangsangan dan memfasilitasi perkembangannya. Semakin banyak rangsangan terhadap otak anak, maka akan semakin banyak peluang tumbuhnya cabang-cabang baru neuron sehingga semakin terbuka peluang menjadi sukses (Masnipal, 2013: 80).

Lebih lanjut Martinis Yamin dan Jamilah Sabri Sanan mengungkapkan bahwa tumbuhnya cabang-cabang baru neuron akan berpengaruh terhadap struktur otak. Dengan demikian struktur otak pada anak dipengaruhi oleh pemberian stimulasi edukasi pada anak. Semakin sering anak diberi stimulasi, maka struktur otaknya semakin berkembang dan hal itu akan berpengaruh terhadap masa depannya. Struktur otak pada belahan kiri dan belahan kanan 
pun harus dikembangkan secara seimbang. Pengembangan terhadap otak kiri (belahan kiri) dapat mempengaruhi kemampuan berbahasa, menulis, dan berpikir anak. Sedangkan pengembangan terhadap otak kanan (belahan kanan) dapat mempengaruhi kemampuan emosional, instuisi, dan kreativitas anak (Yamin dan Jamilah Sabri Sanan, 2013: 7).

\section{METODE PENELITIAN}

Penelitian ini merupakan jenis penelitian lapangan (field research) dengan menggunakan pendekatan kualitatif. Metode penelitian yang digunakan adalah metode penelitian kualitatif deskriptif-eksploratif. Sumber data utama dalam penelitian ini adalah sumber data berupa orang (person).Sumber data utama dalam pendekatan kualitatif deskriptif adalah kata-kata dan tindakan dari orang yang diwawancarai, selebihnya adalah data tambahan seperti dokumen dan lain-lain. Berdasarkan hal tersebut, maka subjek dalam penelitian ini antara lain: kepala TK Khalifah Purwokerto, wakil kepala TK Khalifah Purwokerto, guru TK Khalifah Purwokerto, dan anak didik TK Khalifah Purwokerto.

Lokasi penelitian yang dituju penulis adalah TK Khalifah Purwokerto yang beralamatkan di Perumahan Saphire Residence Karangwangkal Blok Zamrud No. N 13/14 Kelurahan Tambaksari Kidul, Kecamatan Kembaran, Purwokerto, Jawa Tengah. Berdasarkan subjek dalam penelitian ini data akan dikumpulkan dengan menggunakan tiga teknik, yaitu wawancar, observasi, dan dokumentasi. Teknik analisis data yang digunakan dalam penelitian ini adalah teknik analisis data kualitatif menggunakan pendekatan induktif umum. Teknik analisis data tersebut tepat untuk digunakan dalam penelitian dengan metode kualitatif.Pada teknik analisis data kualitatif menggunakan pendekatan induktif umum dilakukan tiga kegiatan, yaitu transkrip, pengorganisasian data, dan koding. Untuk memeriksa keabsahan data, penulis menggunakan teknik triangulasi teknik pengumpulan data. Pada teknik ini penulis melakukan cross check terhadap berbagai data hasil dari wawancara, observasi dan dokumentasi.

\section{HASIL DAN PEMBAHASAN}

\section{Perencanaan Program Kegiatan PAUD Berbasis Otak Kanan di TK Khalifah Purwokerto}

Pada tahap perencanaan dapat diketahui bahwa optimalisasi perkembangan otak kanan pada anak usia dini di TK Khalifah Purwokerto dilakukan melalui penetapan tauhid dan entrepreneur sebagai nilai yang akan diinternalisasikan pada anak usia dini. Penetapan tersebut berlandaskan pada misi dan hasil pendidikan TK Khalifah Purwokerto. Ketercapaian misi dan hasil pendidikan tersebut akan berimplikasi pada ketercapaian visi TK Khalifah Purwokerto. 
Berdasarkan nilai tauhid dan entrepreneur tersebut kemudian dirumuskanlah tema pembelajaran. Hal itu menjadikan suatu tema pembelajaran memiliki konsep ketuhanan dan konsep entrepreneur. Misalnya pada tema berikut ini:

a. Ramadhan bulan berkah untuk ibadah dan menjadi pengusaha (konsep ibadah sebagai representasi dari tauhid dan konsep pengusaha sebagai representasi dari nilai entrepreneur).

b. Pasar tempat jual beli sarana datangnya rezeki dari Allah (konsep pasar merupakan representasi dari nilai entrepreneur dan konsep rezeki dari Alah merupakan representasi dari nilai tauhid).

Namun sayang tema-tema pembelajaran pada TK Khalifah Purwokerto terlalu panjang untuk ukuran anak usia dini. Hal itu menjadikan anak sulit untuk memahaminya. Menurut penulis perlu dilakukan pemadatan penggunaan kata pada tema pembelajaran yang telah ditentukan. Misalnya untuk tema "pasar tempat jual beli sarana datangnya rezeki dari Allah", dipadatkan menjadi "berdagang diberkahi Allah".

Setiap tema pembelajaran memiliki goals tema. Berdasarkan tema pembelajaran dan goals tema disusunlah indikator kemampuan tauhid dan entrepreneur. Indikator kemampuan tersebutlah yang dijadikan sebagai pedoman untuk membuat RKH dan menyusun instrumen penilaian.

Indikator kemampuan tauhid dan entrepreneur pada dasarnya mendeskripsikan bagaimana profil lulusan dari TK Khalifah Purwokerto, yaitu menghasilkan anak usia dini yang beriman dan berjiwa entrepreneur. Profil lulusan tersebut sesuai dengan misi TK Khalifah Purwokerto, yaitu memastikan anak bercita-cita menjadi moslem-entrepreneur dengan keteladanan Nabi Muhammad SAW.

Dengan demikian dapatlah dikatakan perencanaan yang disusun oleh pihak manajemen TK Khalifah Purwokerto sudah menerapkan prinsip relevansi dan prinsip berorientasi pada tujuan. Namun sayangnya perencanaan dibuat bukan oleh guru di TK Khalifah Purwokerto, tetapi dibuat oleh pihak manajemen TK Khalifah Pusat. Ini dilakukan agar standar yang sama antar TK Khalifah yang ada di Indonesia. Ini juga dilakukan untuk mewujudkan visi TK Khalifah.

Ini merupakan konsekuensi logis yang harus diterima oleh TK Khalifah Purwokerto sebagai cabang dari TK Khalifah Pusat. Hal ini menjadikan guru di TK Khalifah Purwokerto kurang inovatif dalam menyusun rencana program kegiatan PAUD berbasis otak kanan. Rencana 
kegiatan semesteran menjadi satu-satunya bentuk perencanaan yang dibuat oleh guru di TK Khalifah Purwokerto.

\section{Pengorganisasian Program Kegiatan PAUD Berbasis Otak Kanan di TK Khalifah Purwokerto}

Berdasarkan hasil penelitian dapat diketahui bahwa kepala TK Khalifah Purwokerto menjadi fasilitator dalam pelaksanaan program kegiatan PAUD berbasis otak kanan. Sedangkan wakil kepala TK menjadi desainernya. Kemudian guru menjadi implementatornya dan guru pendamping menjadi suporter pelaksana. Implikasinya adalah adanya tugas pokok dan fungsi dari masing-masing personal atau unit kerja yang jelas. Hal itu dapat menjadikan kerja kepala TK, wakil kepala TK, guru dan guru pendamping lebih terorganisir dan tidak terjadi overlapping pekerjaan. Berdasarkan pembagian kerja tersebut idealnya pihak manajemen TK Khalifah Purwokerto membuat struktur organisasi TK Khalifah Purwokerto.

Peran kepala TK, wakil kepala TK, guru dan guru pendamping juga didukung oleh keberadaan anggaran yang memadai dalam pelaksanaan program kegiatan PAUD berbasis otak kanan. Hal itu menjadikan berbagai sarana dan prasarana yang dibutuhkan dalam pelaksanaan program kegiatan PAUD berbasis otak kanan dapat diadakan. Namun sayangnya penggunaan sarana dan prasarana tersebut belum dibarengi dengan pembuatan prosedur penggunaannya (semacam SOP/standard operating procedures). Prosedur tersebut sangatlah penting untuk dibuat dengan harapan agar sarana dan prasarana yang ada benar-benar dapat diberdayakan secara efektif dan efisien.

Berdasarkan hasil penelitian juga dapat diketahui bahwa pihak manajemen TK Khalifah Purwokerto melakukan koordinasi dan komunikasi dengan orang tua untuk mendukung pelaksanaan program kegiatan PAUD berbasis otak kanan. Berbagai media baik media online maupun media cetak di manfaatkan untuk menjalin koordinasi dan komunikasi. Tatap muka juga dilakukan untuk menjalin koordinasi dan komunikasi.

Keterbukaan dan kepuasan pelanggan menjadi dua prinsip yang diaktualisasikan dalam menjalin hubungan dengan orang tua untuk kepentingan pelaksanaan program kegiatan PAUD berbasis otak kanan. Hal itu akan lebih optimal lagi untuk dilakukan ketika kepala TK Khalifah mau dan mampu menerapkan model kepemimpinan partisipatif. Pada model kepemimpinan tersebut kepala TK Khalifah Purwokerto melibatkan orang tua dalam menyusun program kegiatan PAUD berbasis otak kanan sekaligus mengajak orang tua untuk mengevaluasi program tersebut. 


\section{Pelaksanaan Program Kegiatan PAUD Berbasis Otak Kanan di TK Khalifah Purwokerto}

Berdasarkan hasil penelitian dapat diketahui bahwa optimalisasi perkembangan otak kanan pada anak usia dini dilakukan melalui internalisasi nilai tauhid dan entrepreneur pada anak usia dini. Internalisasi tersebut dilakukan melalui pelaksanaan pembelajaran tematik dan kegiatan pembiasaan (pembiasaan rutin dan pembiasaan spontan).

Jalannya pelaksanaan pembelajaran sentra didukung oleh pelaksanaan kegiatan pembiasaan. Pembelajaran sentra dan kegiatan pembiasaan dilaksanakan secara saling beriringan. Pada kegiatan ini dilakukan tiga kegiatan:

a. Pengenalan terhadap nilai tauhid dan entrepreneur (knowing about tauhid and entrepreneur values).

b. Pemberian pemahaman kepada anak untuk mengaktualisasikan nilai tauhid dan entrepreneur (undestanding to acting).

c. Pembiasaan untuk mengaktualisasikan mengaktualisasikan nilai tauhid dan entrepreneur (habituation about tauhid and entrepreneur values).

Ketiga kegiatan tersebut harus dilaksanakan secara sinergis dan berkesinambungan. Kemudian Agar mendapatkan hasil yang radiks dan komprehensif, guru tidak boleh fokus pada satu kegiatan saja dan juga tidak boleh ada satu kegiatan pun yang ditinggalkan. Ketiga kegiatan tersebut harus ada dan dilaksanakan.

\section{Penilaian Program Kegiatan PAUD Berbasis Otak Kanan di TK Khalifah Purwokerto}

Berdasarkan hasil penelitian dapat diketahui bahwa bentuk penilaian dalam program kegiatan PAUD berbasis otak kanan di TK Khalifah Purwokerto adalah assesment harian, assesment mingguan, assesment tengah semesteran, assesment semesteran dan buku penghubung. Indikator kemampuan tauhid dan entrepreneur menjadi acuan dalam menyusun instrumen assesment tersebut. Sementara itu buku penghubung dijadikan sebagai instrumen untuk memonitoring perilaku anak di TK Khalifah Purwokerto oleh guru dan orang tua.

Penyusunan assesment yang didasari pada indikator kemampuan tauhid dan entrepreneur menjadikan adanya relevansi antara RKH dengan instrumen assesment. Implikasinya adalah assesment yang dilakukan benar-benar dapat dijadikan sebagai alat untuk mengukur keberhasilan program kegiatan PAUD berbasis otak kanan. 
Berdasarkan hasil penelitian dapat diperoleh informasi bahwa TK Khalifah Purwokerto menerapkan model Total Quality Management (TQM) dalam melaksanakan program kegiatan PAUD berbasis otak kanan. Indikatornya yaitu:

1. Memiliki visi, misi, tujuan, dan filosofi yang jelas.

Pada praktik TQM lembaga pendidikan membedakan visi, misi, tujuan dan filosofinya. Ada tiga alasan mengapa hal itu dilakukan, yaitu:

a. Untuk memperjelas jenis ataupun karakteristik lembaga pendidikan dengan lembaga pendidikan lainnya.

b. Untuk mendeskripsikan harapan lembaga pendidikan ke depannya.

c. Untuk memperjelas arah mana yang hendak dituju.

Hal di atas juga dilakukan oleh TK Khalifah Purwokerto yang memiliki visi, misi, tujuan dan filosofi yang jelas dan berbeda dengan lembaga PAUD lainnya. Visi TK Khalifah Purwokerto adalah "menjadi salah satu TK atau KOBER Islam favorit di Indonesia. Sedangkan misinya adalah memastikan anak bercita-cita menjadi moslem-entrepreneur dengan keteladanan Nabi Muhammad SAW."

Sementara itu, tujuan TK Khalifah Purwokerto adalah untuk membantu pemerintah dalam menyediakan program Pendidikan Anak Usia Dini (PAUD) yang berkualitas untuk meningkatkan kualitas sumber daya manusia dalam rangka mewujudkan pendidikan nasional, yaitu mencerdaskan kehidupan bangsa dan mengembangkan manusia Indonesia seutuhnya.

Kemudian filosofi dari TK Khalifah Purwokerto dapat terdeskripsikan melalui konsep "tauhid-entrepreneur" dan "pengusaha-sedekah". Dua konsep tersebut menjadi kata kunci dalam pelaksanaan program kegiatan PAUD berbasis otak kanan. Konsep tauhid-entrepreneur menjadi nilai yang diinternalisasikan pada diri anak usia dini melalui kegiatan pembelajaran tematik dan pembiasaan. Nilai tauhid didasari oleh QS. Luqman ayat 13-20.

Pelaksanaan program kegiatan PAUD berbasis otak kanan diarahkan untuk menguatkan keimanan anak usia dini. Indikasi dari keimanan yang kuat yaitu:

a. Tidak berbuat syirik (ayat 13 ).

b. Berbakti kepada orang tua (ayat 14).

c. Lemah-lembut kepada orang tua (ayat 15).

d. Bertanggungjawab (ayat 16).

e. Mengerjakan sholat, beramar ma'ruf nahi munkar, dan bersabar (ayat 17).

f. Tidak sombong dan angkuh (ayat 18). 
g. Rendah hati (ayat 19).

h. Berilmu pengetahuan (ayat 20).

Kemudian nilai entrepreneur didasari oleh fakta sejarah bahwa Nabi Muhammad SAW sudah diajarkan oleh pamannya (Abu Thalib) menggembala kambing. Nabi Muhammad SAW juga diajarkan berdagang oleh pamannya. Pamannya mengajaknya pergi berdagang ke Syam ketika berusia 12 tahun.Menggembala kambing bukanlah sesuatu yang mudah. Pada masa kanak-kanaknya Nabi Muhammad SAW bisa menggembala kambing dengan baik. Nabi Muhammad SAW mampu melayani kambing-kambingnya sehingga tidak kelaparan, kehausan dan aman.

Pada saat melayani kambing-kambingnya, Nabi Muhammad SAW pada dasarnya sedang mempraktekkan konsep kepemimpinan, yaitu kepemimpinan yang melayani yang saat ini populer dengan istilah service leadership. Karakter kepemimpinan yang melayani tersebut sangat dibutuhkan oleh seorang pengusaha (entrepreneur) dalam berwirausaha.

Pada saat menggembala kambing, Nabi Muhammad SAW juga sedang mempraktikkan konsep manajemen. Nabi Muhammad SAW tahu betul mengapa ia beliau harus menggembala kambing. Ini menunjukkan bahwa beliau memiliki tujuan utama dari penggembalaan tersebut. Nabi Muhammad SAW juga tahu kapan waktunya memberi makan dan minum kambingkambingnya (planning), bagaimana caranya agar kambing-kambingnya tidak bercerai-berai (organizing), mengarahkan agar kambingnya tetap dalam kontrolnya (actuating), dan mengamati keadaan serta menghitung jumlah kambingnya (controlling). Keempat kompetensi manajerial tersebut tersebut sangat dibutuhkan oleh seorang pengusaha dalam mengelola usahanya.

Kemudian pada konsep "pengusaha-sedekah" anak diberi pemahaman bahwa profesi yang paling utama adalah wirausaha. Ketika anak di lembaga PAUD lain memiliki cita-cita ingin menjadi dokter, bidan, perawat, polisi, tentara, pegawai bank, bahkan presiden, anak di TK Khalifah memiliki cita-cita menjadi pengusaha, seperti pengusaha catering, pengusaha kolam renang, pengusaha sosis, pengusaha baju, pengusaha jilbab, pengusaha otomotif, pengusaha bunga hingga pengusaha handphone.

Guru menanamkan pemahaman kepada anak bahwa profesi sebagai pengusaha telah dilakukan oleh Nabi Muhammad SAW sebagai seorang pedagang. Dengan menjadi pengusaha kelak anak tidak meminta pekerjaan tetapi membuka lapangan kerja. Hal itu akan lebih membawa kemanfaatan bagi sesama. Kemanfaatan bagi sesama tersebut akan lebih bermakna lagi ketika anak mau mensedekahkan hasil usahanya kepada sesamanya. 
Agar hasil usahanya lancar dan diberkahi Allah serta cukup kebutuhan sehari-hari dan untuk bersedekah, anak diberi pemahaman oleh guru bahwa bekerja harus dibarengi dengan beribadah. Salah satunya adalah dengan melaksanakan sholat dhuha setiap hari, di mana sholat dhuha merupakan sholat pembuka pintu rezeki dan sholat yang bernilai sedekah.

2. Memiliki kurikulum yang memiliki standar mutu pendidikan.

Dalam perspektif TQM, standar mutu pendidikan berupa kepemilikan atau akuisisi kemampuan dasar pada masing-masing bidang pembelajaran. Standar mutu pendidikan tersebut dideskripsikan pada kurikulum yang dikembangkan serta dilaksanakan dan standar evaluasi yang dirumuskan. Standar evaluasi dijadikan sebagai alat untuk mengukur keberhasilan pembelajaran yang mengarah pada standar mutu pendidikan. Standar mutu pendidikan pada TK Khalifah Purwokerto tercermin dalam hasil pendidikan (output) yang hendak dicapainya, yaitu:

a. Anak mampu mengenal diri dan alam lingkungannya sebagai makhluk ciptaan Allah.

b. Anak mengagumi ciptaan Allah.

c. Anak dapat mengenal bahwa Allah Maha Pengasih, Maha Penyayang, Maha Pandai, Maha Mengetahui, Maha Kaya, Maha Melihat, dan Maha Mendengar.

d. Anak dapat menirukan, melakukan gerakan dan bacaan sholat, ikrar, doa-doa harian, dan kalimat-kalimat thayyibah sesuai dengan kemampuannya.

e. Anak dapat mensyukuri bahwa Allah Maha Pengasih dan Penyayang yang telah memberikan kemampuan untuk bermain sambil belajar dengan berbagai macam alat permainan untuk mengembangkan kemampuannya.

f. Anak dapat melakukan dan mengekspresikan segala macam daya kreasinya sebagai anugerah dari Allah.

g. Anak senang bermain sambil belajar, mencintai ilmu, dan ingin belajar terus-menerus.

h. Anak mengenal Nabi dan para sahabat.

i. Anak bersikap santun dan mengenal nilai dasar entrepreneur.

j. Anak bercita-cita menjadi moslem-entrepteneur.

Kurikulum TK Khalifah dikembangkan dan dilaksanakan untuk mencapai hasil pendidikan di atas. Ada tujuh aspek yang dikembangkan melalui proses pembelajaran, yaitu tauhid, entrepreneurship, akhlak perilaku, keterampilan, kognitif, fisik, dan bahasa.Untuk memastikan bahwa pelaksanaan pembelajaran tematik dapat mengembangkan ketujuh aspek di atas, maka disusunlah Rencana Kegiatan Harian (RKH) yang berstandar dalam bentuk buku Rencana Kegiatan Harian (RKH) sebanyak 4 jilid. Standar RKH di setiap TK Khalifah di seluruh 
Indonesia sama. Ini dilakukan bukan hanya untuk meraih misi, tetapi juga untuk meraih visi TK Khalifah Purwokerto.

RKH dijadikan sebagai acuan dalam melaksanakan program pembelajaran tematik. Pada RKH terdapat tema-tema. Masing-masing tema memiliki goals tema. Berdasarkan tema dan goals tema disusunlah indikator kemampuan pada ketujuh aspek perkembangan. Indikator kemampuan tersebut dijadikan sebagai acuan dalam menyusun instrumen penilaian. Standar evaluasi pada TK Khalifah dideskripsikan dengan buku panduan Assesmen Mingguan yang disusun oleh $R$ and D TK Khalifah Management.

3. Melaksanakan ide zero deffect.

Ide zero deffect (tanpa cacar) merupakan komitmen untuk selalu sukses dan menghilangkan kegagalan. Mengaplikasikan ide ini dalam bidang layanan merupakan sesuatu yang sangat ideal, meski demikian ide ini menjadi sebuah tujuan. Pada ide zero deffect dalam konteks pendidikan, guru menginginkan agar semua anak mendapatkan kesuksesan dan dapat mengembangkan potensi mereka melalui penggunaan sistem pembelajaran yang tepat dan benar dilakukan sejak awal.

TK Khalifah Purwokerto menerapkan sistem pembelajaran BCCT (Beyond Center and Circle Time) yang dalam pelaksanaan kegiatan pembelajarannya guru memberikan pengalaman kepada anak-anak di sentra yang berbeda-beda dan dalam hari yang berbeda pula. Anak-anak belajar melalui kegiatan bermain untuk dapat memahami diri sehingga mampu mengembangkan dirinya. RKH disusun oleh pihak R and D TK Khalifah Management untuk memastikan bahwa jalannya BCCT berlangsung sistematis.

Sentra-sentra yang digunakan sebagai media bermain agar anak mampu memahami diri dan mengembangkan dirinya antara lain:

a. Tauhid Centre

Sentra ini menekankan pada pengenalan dan pembelajaran agama sedini mungkin untuk mengenal Tuhannya dan nilai-nilai agama, terutama kalimat-kalimat tauhid yang mengesakan Allah dan memahami Asmaul Husna, Kegiatan rutin pada sentra ini antara lain wudlu, sholat berjamaah, mengaji, pengenalan surat pendek, dan doa sehari-hari.

\section{b. Life Skill Centre}

Sentra ini dirancang untuk memberikan stimulus kepada anak dalam peningkatan keterampilan sehari-hari, meliputi kemandirian seperti memakai dan melepas bajunya sendiri, memakai dan melepas sepatu, makan dengan sikap yang baik, mengurus keperluannya sendiri 
dan lainnya.Pada sentra ini anak juga dibekali keterampilan dalam bersosialisasi dengan masyarakat seperti saling tolong-menolong, bekerjasama dan lainnya. Selain itu anak juga dibekali bermacam-macam peran di masyarakat seperti pedagang/pengusaha, dokter, guru, ayah/ibu, anak, mengerjakan pekerjaan rumah dan sebagainya dalam bermain peran sehingga tumbuh sikap saling menghargai terhadap orang lain.

c. Art Centre.

Sentra ini bertujuan mengembangkan kemampuan seni rupa, seni bentuk, seni suara, seni musik, seni gerak dan kreativitas anak. Pada sentra ini anak melakukan kegiatan bermain yang dapat mengembangkan kreativitasnya dalam:

1) Seni rupa dan seni bentuk, yaitu menggambar, mewarnai, ekspresi warna, melukis, membentuk, kolase dan mozaik.

2) Pengalaman motorik halus, yaitu menggunting, emronce, menganyam, mencocok, menjahit, dan merobek untuk persiapan menulis.

3) Seni suara dan seni musik, yaitu menyanyi, mengucakan syair, bertepuk pola, membuat dan memainkan alat musik perkusi.

4) Seni gerak, yaitu ritmik, senam, menari, dan pantomin.

4. Bentuk yang ramping dan struktur yang sederhana.

Bentuk yang ramping dan struktur yang sederhana pada organisasi yang mengaplikasikan TQM ditunjukkan dengan menghilangkan sistem hirarki dengan struktur kerja yang sejajar. Bentuk organisasi yang baik dan tepat bagi TQM adalah bentuk yang sederhana, ramping, dan dibangun dalam tim kerja yang kuat.

Pada konteks penyelenggaraan layanan PAUD di TK Khalifah Purwokerto, hal di atas menjadikan banyaknya sumber daya manusia (SDM) bukanlah penentu utama keberhasilan lembaga PAUD dalam mencapai tujuan PAUD. Penentunya adalah efektivitas dan efisiensi kerja guru dan staf sebagai SDM lembaga PAUD. Efektivitas dan efisiensi kerja tersebut ditunjukkan dalam kepemilikan tim kerja yang kuat. Pada TK Khalifah Purwokerto hanya ada 4 guru. 1 guru merangkap sebagai kepala TK dan 1 guru lagi merangkap sebagai wakil kepala TK. Kepala TK dan wakil kepala TK menjadi guru kelas yang dalam melaksanakan program kegiatan PAUD dibantu masing-masing dibantu oleh 1 orang guru. Mereka mampu bekerjasama sebagai team teaching dalam melaksanakan kegiatan pembelajaran dan kegiatan pembiasaan untuk menginternalisasikan nilai tauhid dan entrepreneur pada anak usia dini.

5. Menjaga hubungan baik dengan pelanggan. 
Misi utama dari suatu organisasi yang mempraktikkan TQM adalah untuk memenuhi kebutuhan dan keinginan pelanggannya. Pertumbuhan dan perkembangan suatu organisasi bersumber dari kesesuaian layanan organisasi dengan kebutuhan pelanggan. Dengan kesesuaian tersebut maka hubungan baik antara organisasi dengan pelanggan akan berlangsung baik.Beberapa upaya dilakukan oleh TK Khalifah Purwokerto untuk menjaga hubungan baik dengan pelanggan. Upaya tersebut antara lain:

a. Menerima masukan dari orang tua terkait dengan program kegiatan PAUD berbasis otak kanan yang hendak dilaksanakan. Masukan tersebut diakomodir dan diwujudkan dalam penyusunan rencana kegiatan semesteran.

b. Mensosialisasikan rencana kegiatan TK Khalifah Purwokerto kepada wali murid secara langsung dalam rapat-rapat maupun secara tidak langsung melalui parents handbook dan grup What's Up.

c. Mengkomunikasikan perkembangan anak di setiap harinya kepada orang tua melalui buku penghubung.

d. Mendengarkan keluhan dari orang tua dan menindaklanjutinya dengan melakukan upaya perbaikan program kegiatan PAUD berbasis otak kanan.

e. Meminimalisir keluhan dari orang tua terkait dengan pelaksanaan program kegiatan PAUD berbasis otak kanan dengan cara memberikan layanan prima.

\section{SIMPULAN}

Optimalisasi pengembangan otak kanan pada anak usia dini di TK Khalifah Purwokerto dilakukan melalui internalisasi nilai tauhid dan entrepreneur pada anak usia dini. Pembelajaran tematik dan pembiasaan menjadi program kegiatan PAUD yang dijadikan sebagai media internalisasi nilai tauhid dan entrepreneur.

Untuk memastikan proses internalisasi nilai tauhid dan entrepreneur berlangsung dengan efektif dan efisien, maka dilakukanlah empat kegiatan manajerial. Keempat kegiatan manajerial tersebut antara lain:

1. Perencanaan program kegiatan PAUD berbasis otak kanan di TK Khalifah Purwokerto.

Perencanaan program kegiatan PAUD berbasis otak kanan dilakukan dengan menyusun tema dan goals tema pembelajaran, menyusun kegiatan semesteran, membuat acuan tema, dan membuat rencana kegiatan harian $(\mathrm{RKH})$. RKH menjadi satu bentuk rencana program kegiatan PAUD berbasis otak kanan di TK Khalifah Purwokerto yang vital. RKH memuat tema dan goals tema, aspek perkembangan yang dikembangkan (meliputi tauhid, 
entrepreneurship value, akhlak terpuji, keterampilan, kognitif, bahasa, dan fisik), indikator kemampuan pada setiap aspek perkembangan dan deskripsi mengenai kegiatan pembelajaran dan kegiatan pembiasaan yang akan dilaksanakan untuk menginternalisasikan nilai tauhid dan entrepreneur. Kepemilikan dokumen RKH yang lengkap menunjukkan matangnya perencanaan program kegiatan PAUD berbasis otak kanan.

2. Pengorganisasian program kegiatan PAUD berbasis otak kanan di TK Khalifah Purwokerto. Pengorganisasian program kegiatan PAUD berbasis otak kanan di TK Khalifah Purwokerto dilaksanakan melalui pembagian kerja guru, penggalangan anggaran pendidikan, pengadaan sarana dan prasarana pendidikan, serta menjalin koordinasi dan komunikasi dengan wali murid.Dengan dilaksanakannya pengorganisasian yang rapih, dapat diketahui tugas dan tanggungjawab stakeholders PAUD dalam pelaksanaan program kegiatan PAUD berbasis otak kanan. Anggaran pendidikan yang memadai menjadikan pihak TK Khalifah Purwokerto mampu mengadakan sarana dan prasarana yang digunakan untuk mendukung pelaksanaan program kegiatan PAUD berbasis otak kanan.

3. Pelaksanaan program kegiatan PAUD berbasis otak kanan di TK Khalifah Purwokerto.

Ada dua bentuk kegiatan dalam pelaksanaan program kegiatan PAUD berbasis otak kanan di TK Khalifah Purwokerto, yaitu kegiatan pembelajaran tematik dan kegiatan pembiasaan. Ada dua jenis kegiatan pembiasaan, yaitu pembiasaan rutin dan pembiasaan spontan. Kedua jenis kegiatan pembiasaan tersebut dilaksanakan berbarengan dengan pelaksanaan kegiatan pembelajaran tematik. Hal itu menjadikan ada keterpaduan antara kegiatan pembelajaran tematik dan kegiatan pembiasaan. Internalisasi nilai tauhid dan entrepreneur dapat berlangsung secara efektif dan efisien dengan adanya keterpaduan kedua kegiatan tersebut.

4. Penilaian program kegiatan PAUD berbasis otak kanan di TK Khalifah Purwokerto.

Penilaian program kegiatan PAUD berbasis otak kanan di TK Khalifah Purwokerto dilaksanakan dengan melakukan assesment harian, assesment mingguan, assesment tengah semester, assesment semesteran, dan buku penghubung.Semua bentuk penilaian di atas dilakukan dengan menggunakan teknik observasi. Perilaku anak diamati berdasarkan indikator kemampuan pada aspek tauhid, entrepreneur value, keterampilan, bahasa, kognitif, dan fisik yang telah ditentukan dalam RKH.

Implementasi model Total Quality Management (TQM) di TK Khalifah Purwokerto ikut mendukung dalam keempat kegiatan manajerial di atas. Ada lima prinsip TQM yang diaktualisasikan oleh TK Khalifah Purwokerto dalam optimalisasi perkembangan otak kanan 
anak. Pertama, memiliki visi, misi, tujuan, dan filosofi yang jelas.Kedua, memiliki kurikulum yang memiliki standar mutu pendidikan.Ketiga, melaksanakan ide zero deffect.Keempat, memiliki bentuk yang ramping dan struktur yang sederhana.Kelima, menjaga hubungan baik dengan pelanggan.

\section{DAFTAR PUSTAKA}

Asmani, Jamal Ma'mur. 2012. Tips Sakti Membangun Organisasi Sekolah. Yogyakarta: Diva Press.

BM Wara Kushartanti, Optimalisasi Otak dalam Sistem Pendidikan Berperadaban, sumber http://staff.uny.ac.id/sites/default/files/131405898/Optimalisasi\%20Otak\%20Dalam\%20Si stem\%20Pendidikan\%20Berperadaban.pdf

Kimani, Gerald Ngugi. tt. Educational Management. South Africa: African Virtual University.

Kurniasih, Imas. 2010. Mendidik SQ Anak Menurut Nabi Muhammad SAW. Yogyakarta: Pustaka Marwa.

Masnipal. 2013. Siap Menjadi Guru dan Pengelola PAUD Profesional. Jakarta: Elex Media Komputindo.

Masruroh, Ninik. 2014. Manajemen Inovasi Pembelajaran: Studi Multi Situs Penerapan Metode Sentra dan Lingkaran pada PAUD Unggulan Nasional Berbasis Islam di Tiga Kota Jawa Timur. Jakarta: Mitra Wacana Media.

Muhammad, As'adi. 2009. Menghidupkan Otak Kanan Anak Anda. Yogyakarta: Powerbooks Publishing.

Mulyani, Novi. 2016. Dasar-Dasar Pendidikan Anak Usia Dini. Yogyakarta: Teras.

Mulyasa,E. 2013. Manajemen Pendidikan Karakter. Jakarta: Bumi Aksara.

Mulyasa, E. 2014. Manajemen PAUD. Bandung: Rosda.

Mursid. 2015.Belajar dan Pembelajaran PAUD. Bandung: Rosda.

Musbikin, Imam. 2013. Menjadi Kepala Sekolah yang Hebat. Riau: Zanafa Publishing.

Ningsih, Tutuk. 2015. Implementasi Pendidikan Karakter. Purwokerto: STAIN Press.

Rachmawati, Yeni dan Euis Kurniati. 2010.Strategi Pengembangan Kreativitas pada Anak Usia Taman Kanak-kanak. Jakarta: Kencana.

Risaldy, Sabil. 2014. Manajemen Pengelolaan Sekolah Usia Dini. Jakarta: Luxima.

Samani, Muchlas dan Hariyanto. 2011.Pendidikan Karakter: Konsep dan Model. Bandung: Rosda.

Satibi, Otib. 2013. Pengembangan Agama dan Moral Anak Usia Dini. Jakarta: Universitas Terbuka.

Sulistyorini. 2009.Manajemen Pendidikan Islam: Konsep, Strategi, dan Aplikasi. Yogyakarta: Teras.

Suyadi dan Maulidya Ulfah. 2013.Konsep Dasar PAUD. Bandung: Rosda.

Suyadi dan Maulidya Ulfah. 2013.Konsep Dasar PAUD. Bandung: Rosda.

Suyadi. 2015.Cerdas dengan Spiritual Educational Games. Yogyakarta: Saufa.

Umiarso dan Imam Gojali. 2010.Manajemen Mutu Sekolah di Era Otonomi Pendidikan. Yogyakarta: IRCiSoD.

Yamin, Martinis dan Jamilah Sabri Sanan. 2013.Panduan PAUD: Pendidikan Anak Usia Dini. Jakarta: Referensi. 